\title{
Analysis of Palatal Rugae Morphology Before and After Orthodontic Treatment by a Digital Image Recognition System
}

\author{
Análisis de la Morfología de las Rugas Palatinas Antes y Después de Tratamiento \\ Ortodóncico por un Sistema de Reconocimiento por Imágenes Digitales
}

\author{
Xiu-Ping Wu' ; Jian-Ning Han²; Pan Fen ${ }^{1} \&$ Yu-Jin Wan³ \& Li Bing ${ }^{1}$
}

XIU-PING, W.; JIAN-NING, H.; PAN, F.; YU-JIN, W. \& LI, B. Analysis of palatal rugae morphology before and after orthodontic treatment by a digital image recognition system. Int. J. Morphol., 35(2): 420-424, 2017.

SUMMARY: To analyze the accuracy rate of a digital image recognition system in matching the palatal rugae Morphology after orthodontic treatment, before orthodontic treatment and to provide theoretical evidence for individual identification in the field of forensic dentistry. High-resolution digital images of the palatal rugae were taken under particular conditions from each patient before and after orthodontic treatment. Features of each digital image were extracted using a digital image recognition system and included in the palatal rugae database. Using an MATLAB software system, information matching of the palatal rugae was performed. From the matching results, the accuracy rate of individual identification of orthodontic patients was $100 \%$, with a Euclidean distance of 0 . The accuracy rate in matching palatal rugae patterns before and after orthodontic treatment was $95.67 \%$. The results were statistically significant with $\mathrm{P}<$ 0.05. Palatal rugae pattern is highly individual-specific. After orthodontic treatment, palatal rugae are morphologically diverse, but these changes do not greatly influence the individual identification in the field of forensic dentistry, which provides a new method of and pathway to forensic identification.

KEY WORDS: Forensic anthropology; Forensic stomatology; Palatal rugae; Identification; Orthodontic treatment.

\section{INTRODUCTION}

Forensic identification is a challenging work that has been always an area of interest in the field of forensic science all over the world ( Gondivkar et al., 2011; Rath \& Reginald, 2014; Bing et al., 2014;Patil et al., 2016;). The pattern of human palatal rugae has a genetic gene-matched individualspecific feature which remains unchanged during an individual's lifetime. Therefore, palatal rugae pattern has gradually become a new marker in the identification of forensic science Ohtani et al., 2008; Adisa et al., 2014; Bhagwath \& Chandra, 2014; Wu et al., 2016. After orthodontic treatment, palatal rugae are morphologically diverse, but these changes do not greatly influence individual identification in the field of forensic dentistry. Shukla et al., 2011; Deepak et al., 2014. In this study, we took digital images of the palatal rugae under particular conditions from each patient before and after orthodontic treatment and then processed using a digital image recognition system, including noise reduction, contrast enhancement, image segmentation, feature extraction, edge detection and information collection
Wu et al. Using an MATLAB software system, information matching of the palatal rugae was performed (Taneva et al., 2015).The morphological characteristics and stability of the palatal rugae were evaluated to investigate the significance of palatal rugae patterns in the individual identification using forensic odontology techniques and the influences of palatal rugae pattern changes after orthodontic treatment on the reliability of individual identification, which will provide a novel method of and pathway to forensic identification.

\section{MATERIAL AND METHOD}

Seventy patients, consisting of 35 males and 35 females, who received treatment in the Department of Orthodontics, Shanxi Medical University Stomatological Hospital, China, between June and December 2015, were included in this study after screening against the inclusion

\footnotetext{
${ }^{1}$ Stomatology Hospital, Shanxi Medical University, Taiyuan, China.

${ }^{2}$ School of Information and Communication Engineering, North University of China, Taiyuan, China.

${ }^{3}$ School of Forensic Medicine, Shanxi Medical University, Taiyuan, China.

Funding: Doctoral Fund of Shanxi Medical University, No. 03201428.
} 
and exclusion criteria. Inclusion criteria: (1) age $\geq 18$ years; (2) having no history of skull and jaw trauma; (3) having permanent dentition before orthodontic treatment; (4) subjected to orthodontic treatment with straight wire for 1224 months. Exclusion criteria: (1) having congenital anomalies/malformations; (2) bone and soft tissue protrusion, active lesions; (3) palatal deformity, scars or trauma; (4) mouth opening limited; (5) having a history of wearing a maxillary denture; (6) smoking.

Instruments and software. Digital SLR cameras (Canon EOS 300D); light reflector for orthodontic surgery; MATLAB software for performing numerical calculations (MathWorks, USA); PRCSVersion 2.0 software; SPSS13.0 software.

Harvesting of palatal rugae images. High-resolution digital images of the palatal rugae were taken from each individual using a digital SLR camera with the same parameters at the designated position. For each individual, two sets of digital images of the palatal rugae were separately taken before (groups A and A') and after orthodontic treatment (groups B and B'). Four sets of digital images taken from each individual were numbered 1a, 1a', 1b, 1b'; 2a, 2a', 2b, 2b'; 3a, 3a', 3b, 3b'... 70a, 70a', 70b, 70b'. All palatal rugae images were saved as JPEG files in a designated database.

Feature extraction of palatal rugae images. Taking the center of the palatal rugae images as a reference point, palatal rugae images were sectored and then segmented into $16 \times 4$ $=64$ segments for image segmentation. Digital palatal rugae images were processed using non linear Gabor filter technique for feature extraction and subsequent selective inclusion (Fig.1, Table I).
Individual identification through palatal rugae images. Seventy sets of palatal rugae images (1a, 2a, 3a... 70a) taken before orthodontic treatment from group A were included in the database, and 70 sets of palatal rugae images (1a', 2a', 3a'... 70a') taken before orthodontic treatment from group A' were used for the images to be identified. After 4900 matches, the most similar images included in the database were respectively used as the models of the images to be identified and the accuracy rate of matching palatal rugae image pattern was recorded. Seventy sets of palatal rugae images $(1 \mathrm{~b}, 2 \mathrm{~b}, 3 \mathrm{~b} \ldots$.. 70b) taken after orthodontic treatment were subjected to the same procedure, and after 4900 matches, the accuracy rate of matching was recorded.

Table. I. Palatal rugae morphology feature.

Morphology Features

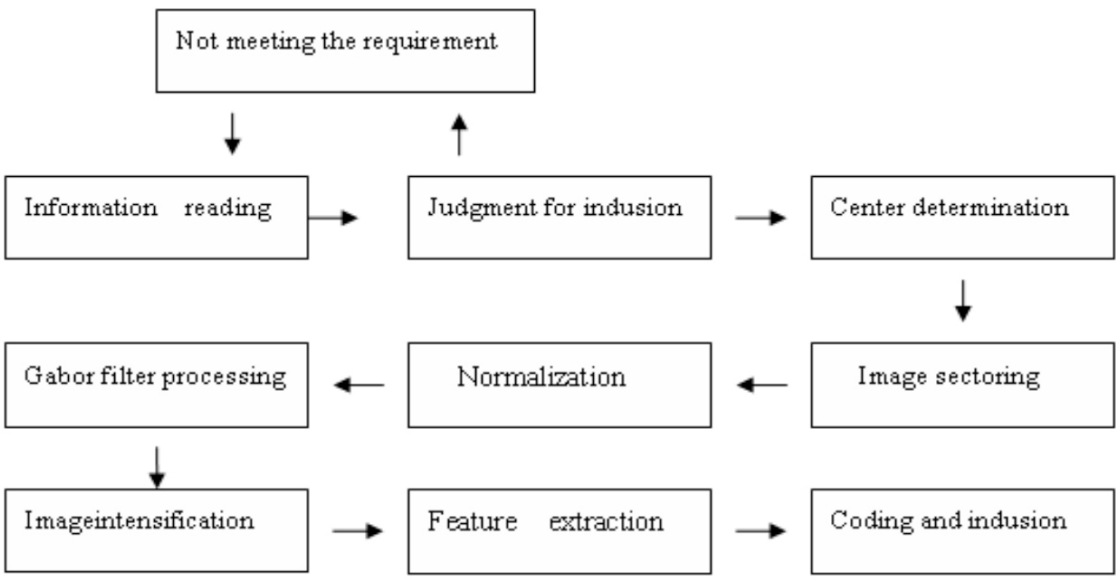

Fig. 1. Inclusion process of palatal rugae images.. 
Matching of palatal rugae images taken before and after orthodontic treatment. Palatal rugae images from group A were randomly selected to match with those in the group B. A "successful match" is displayed on the screen of the digital recognition system, which indicates that these two images are from the same individual. A new match will be started when the first identical authentication is unsuccessful, and "no match" is displayed when the processed data are not identical to the information of any identify throughout the database. The procedure of image processing by the digital recognition system is shown (Figs. 2 and 6)

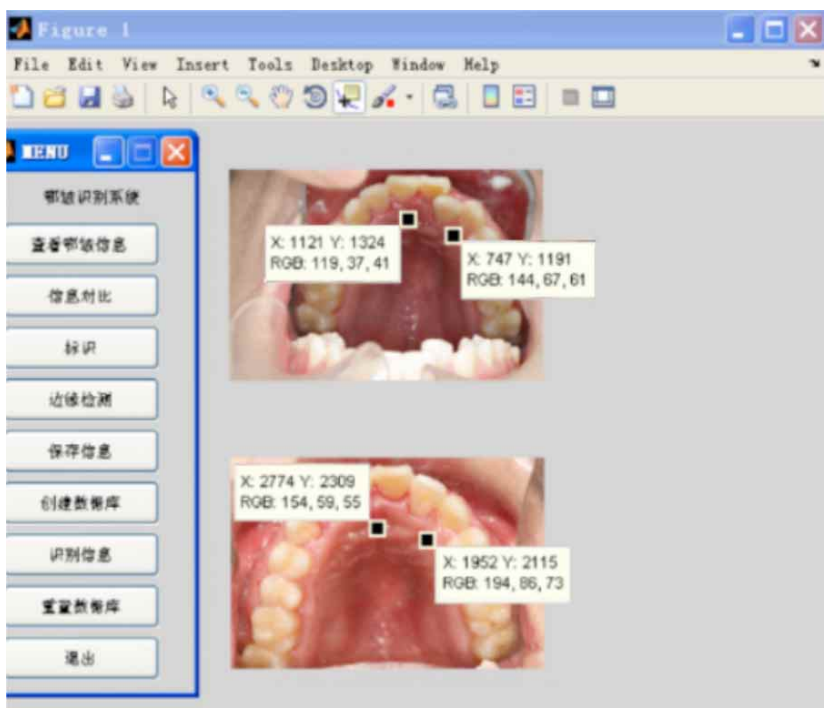

Fig. 2. Contrast of palatal rugae images.

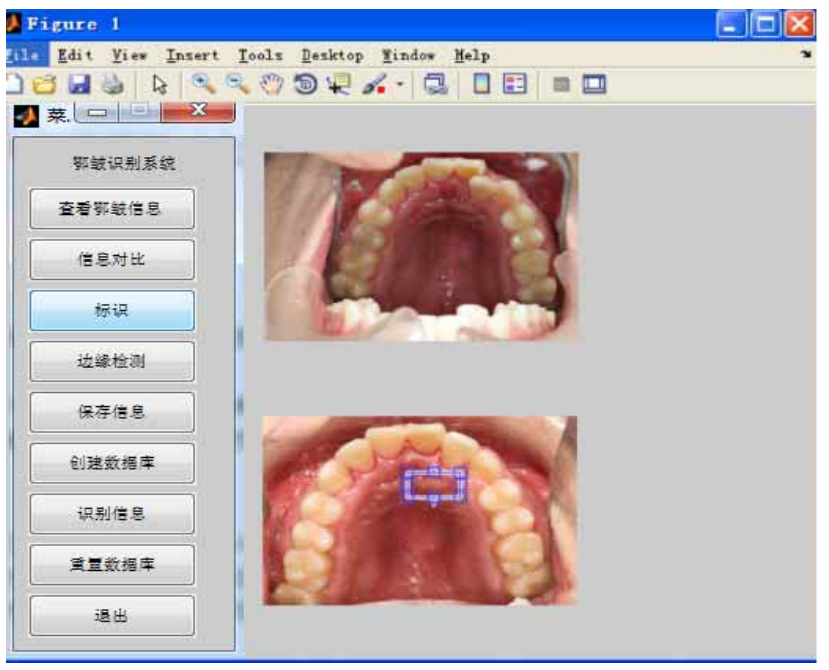

Fig. 3. Markers on the palatal rugae region.

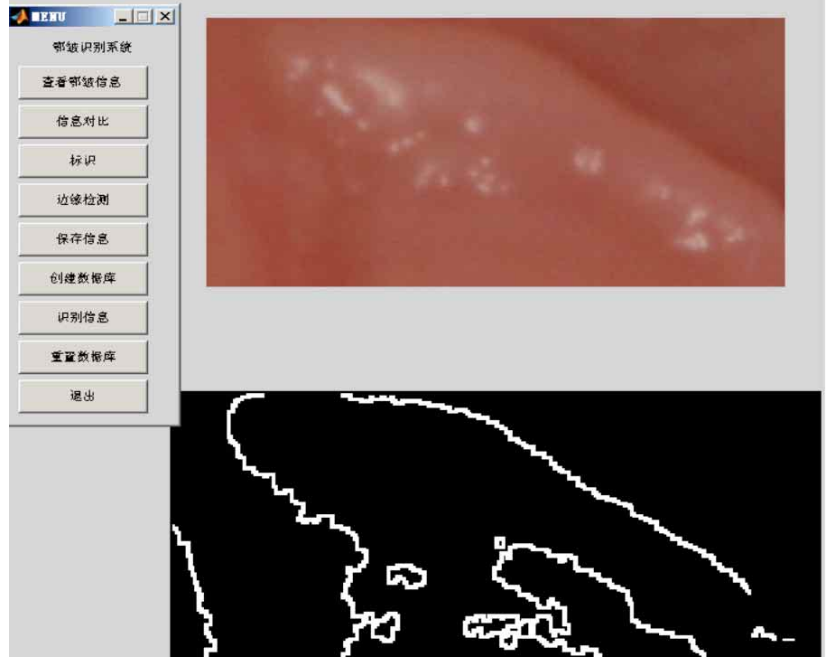

Fig. 4. Detection of palatal rugae edge.

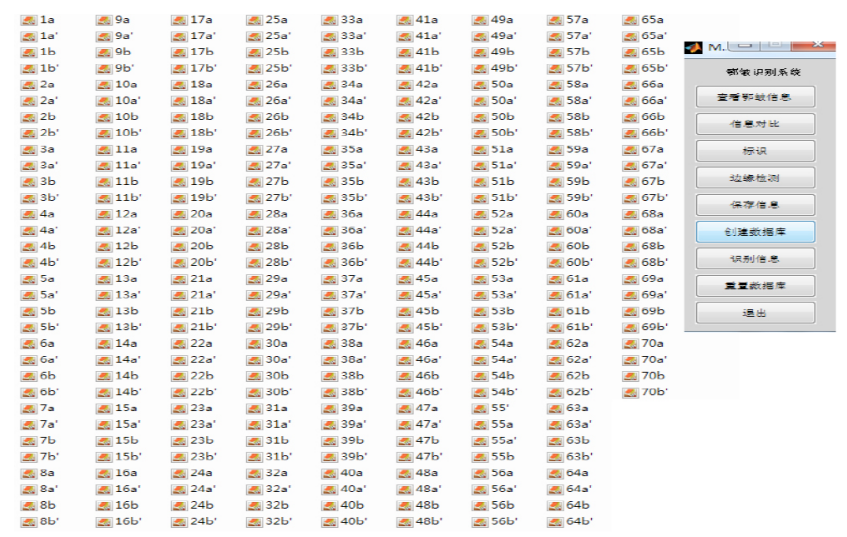

Fig. 5. Palatal rugae images and database establishment.

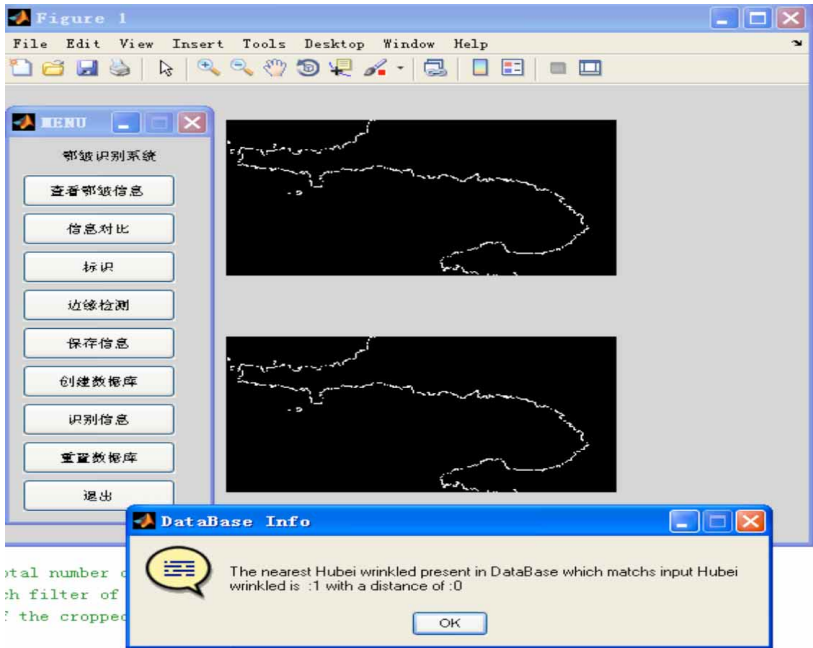

Fig. 6. Identification of palatal rugae information. 


\section{RESULTS}

Identification of individuals using the palatal rugae images. Palatal rugae pattern is highly individual specific. The accuracy rate of matching palatal rugae pattern for individual identification using the digital recognition image system was $100 \%$.

Matching palatal rugae patterns before and after orthodontic treatment. The accuracy rate of matching palatal rugae patterns before and after orthodontic treatment was $95.67 \%$ with a significance level of $\mathrm{P}<0.05$ (Tables II and III, Fig.7).

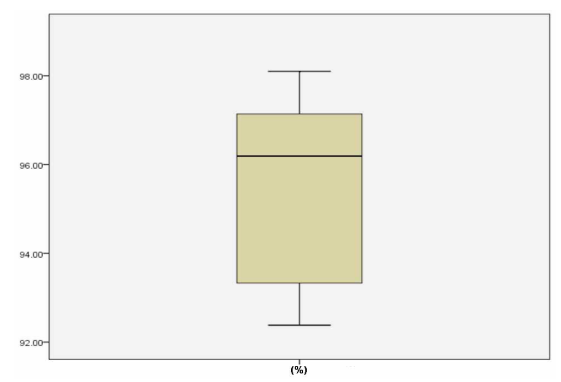

Fig. 7. A box diagram regarding the average accuracy rate of matching palatal rugae patterns before and after orthodontic treatment.

Table. II. The average accuracy rate of matching palatal rugae patterns before and after orthodontic treatment.

\begin{tabular}{ccc}
\hline Individual & Accuracy rate $(\%)$ & Difference $(\mathrm{d})$ \\
\hline 1 & 92.38 & 7.62 \\
2 & 95.71 & 4.29 \\
3 & 97.14 & 2.86 \\
4 & 97.14 & 2.86 \\
5 & 93.33 & 6.67 \\
6 & 96.67 & 3.33 \\
7 & 93.33 & 6.67 \\
8 & 95.71 & 4.29 \\
9 & 97.14 & 2.86 \\
10 & 98.10 & 1.90 \\
\hline
\end{tabular}

Table III. Paired t-test result.

\begin{tabular}{|c|c|c|c|c|c|c|}
\hline & \multirow[b]{2}{*}{$\overline{\mathrm{d}}$} & \multirow[b]{2}{*}{$\mathrm{Sd}$} & \multicolumn{2}{|c|}{$95 \% \mathrm{CI}$} & \multirow[b]{2}{*}{$\mathrm{t}$} & \multirow[b]{2}{*}{$\mathrm{p}$} \\
\hline & & & Lower & Upper & & \\
\hline $\begin{array}{l}\text { Accuracy rate of } \\
\text { matching palatal rugae } \\
\text { patterns before and after } \\
\text { orthodontic treatment } \\
(\%)\end{array}$ & 4.34 & 1.98 & 2.92 & 5.75 & 6.935 & .000 \\
\hline
\end{tabular}

\section{DISCUSSION}

Palatal rugae, also called plicae palatinae transversae, refer to the ridges on the anterior part of the palatal mucosa, each side of the median palatal raphe and behind the incisive papilla. Palatal rugae pattern is a genetic gene-mediated individual-specific feature that differs among individuals and remains unchanged throughout a lifetime. During the process of human development, the palatal rugae possibly change in length and width because of normal growth and development, but its arrangement and position will not change. The morphology and position of the palatal rugae hardly change after diseases, trauma or chemical corrosion. Genetic, unique and stable human palatal rugae patterns contribute to forensic identification (Shetty et al., 2015; Thabitha et al., 2015).

Many scholars consider that orthodontic treatment possibly affects the changes in palatal rugae pattern and therefore application of palatal rugae pattern in the forensic identification becomes more complex (Bailey et al., 1996; Hoggan \& Sadowsky, 200; Mustafa et al., 2015 ). Whether the changes in palatal rugae pattern after orthodontic treatment influence the accuracy of palatal rugae pattern used as a reference in forensic identification remains disputed. It is difficult to measure palatal rugae patterns and there has no well accepted measurement method. Pattern measurement is the first used method, followed by image overlapping method and use of image analysis system. With increasing application of digital computer technology in the academic field, a digital image recognition system comes into being because of demand. The digital image recognition system used in this study for identification of the palatal rugae was co-developed by Professor Bing Li from Shanxi Medical University Stomatological Hospital, China and scholars from School of Information and Communication Engineering, North Central University, China.

Identification of palatal rugae images is performed though image processing, feature extraction and METLAB software analysis. In this study, the accuracy rate of matching the palatal rugae patterns for individual identification was $100 \%$. Martins Filho also reported a $100 \%$ accuracy rate of the digital image recognition system in matching the palatal rugae patterns. Limson \& Julian (2004) used computer software to compare some palatal rugae markers and acquired the accuracy rate of 92-97\%. dos Santos et al. (2011) evaluated and confirmed the efficacy of GNU image method in the forensic identification in a study involving palatal rugae detection. Hemanth et al. (2010) reported that the accuracy rate of palatal rugae comparison software (PRCS version 2.0) was $99 \%$. In this study, the accuracy rate of the digital image recognition system used for matching palatal rugae pattern before and 
after orthodontic treatment was $95.67 \%$, with a significance level of $\mathrm{P}<0.05$. In this study, the resolution of the palatal rugae images directly influences the accuracy rate of identification of the palatal rugae. Therefore, as for the same palatal rugae pattern, several images should be taken to reduce errors and increase accuracy rate in identification. It is very necessary to take highresolution images, maintain and update dental data, in particular after orthodontic treatment, for individual identification.
The digital image recognition system developed based on digital image, computer technology and special digital image authoring software is beneficial to individual identification among large-sized samples and it also simplifies analysis and comparisons of the palatal rugae patterns by human labor, providing important significance for a simple and rapid individual identification.

XIU-PING, W.; JIAN-NING, H.; PAN, F.; YU-JIN, W. \& LI, B. Análisis de la morfología de las rugas palatinas antes y después de tratamiento ortodóncico por un sistema de reconocimiento por imágenes digitales. Int. J. Morphol., 35(2):420-424, 2017.

RESUMEN: El objetivo de este trabajo consistitó en analizar la tasa de exactitud de un sistema de reconocimiento de imágenes digitales en la adaptación de la morfología de la rugosidad palatina después del tratamiento ortodóncico, antes del tratamiento ortodóncico y proporcionar evidencia teórica para la identificación individual en el campo de la odontología forense. Las imágenes digitales de alta resolución de las rugas palatinas fueron tomadas bajo condiciones particulares de cada paciente antes y después del tratamiento ortodóncico. Las características de cada imagen digital se extrajeron utilizando un sistema de reconocimiento de imagen digital y se incluyeron en la base de datos de rugas palatinas. Utilizando el software MATLAB, se realizó la comparación de información de las rugas palatinas. A partir de los resultados coincidentes, la tasa de exactitud de la identificación individual de los pacientes ortodóncicos fue del $100 \%$, con una distancia euclídea de 0 . La tasa de precisión en los patrones de rugas palatinas coincidentes antes y después del tratamiento ortodóncico fue del 95,67\%. Los resultados fueron estadísticamente significativos con $\mathrm{P}<0,05$. El patrón palatino de las rugas es altamente individual-específico. Después del tratamiento ortodóncico, las rugas palatinas son morfológicamente diversas, pero estos cambios no influyen mucho en la identificación individual en el campo de la odontología forense, lo que proporciona un nuevo método y vía para la identificación forense.

PALABRAS CLAVE: Antropología forense; Estomatología forense; Rugas palatinas; Identificación; Tratamiento de ortodoncia.

\section{REFERENCES}

Adisa, A. O.; Kolude, B. \& Ogunrinde, T. J. Palatal rugae as a tool for human identification. Niger. J. Clin. Pract., 17(5):641-3, 2014.

Bailey, L. T.; Esmailnejad, A. \& Almeida, M. A. Stability of the palatal rugae as landmarks for analysis of dental casts in extraction and nonextraction cases. Angle Orthod., 66(1):73-8, 1996.

Bhagwath, S. \& Chandra, L. Rugae pattern in a sample of population of Meerut - An institutional study. J. Forensic Dent. Sci., 6(2):122-5, 2014

Bing, L.; Wu, X. P.; Feng, Y.; Wang, Y. J. \& Liu, H. C. Palatal rugae for the construction of forensic identification. Int. J. Morphol., 32(2):546-50, 2014.

Deepak, V.; Malgaonkar, N. I.; Shah, N. K.; Nasser, A. S.; Dagrus, K. \& Bassle, T. Palatal rugae patterns in orthodontically treated cases, are they a reliable forensic marker? J. Int. Oral Health, 6(5):89-95, 2014.

dos Santos, K. C.; Fernandes, C. M. S. \& Da Costa Serra, M. Evaluation of a digital methodology for human identification using palatal rugoscopy. Braz. J. Oral Sci., 10(3):199-203, 2011.

Gondivkar, S. M.; Patel, S.; Gadbail, A. R.; Gaikwad, R. N.; Chole, R. \& Parikh, R. V. Morphological study of the palatal rugae in western Indian population. J. Forensic Leg. Med., 18(7):310-2, 2011.

Hemanth, M.; Vidya, M.; Shetty, N. \& Karkera, B. V. Identification of individuals using palatal rugae: Computerized method. J. Forensic Dent. Sci., 2(2):86-90, 2010.

Hoggan, B. R. \& Sadowsky, C. The use of palatal rugae for the assessment of anteroposterior tooth movements. Am. J. Orthod. Dentofacial Orthop., 119(5):482-8, 2001.

Limson, K. S. \& Julian, R. Computerized recording of the palatal rugae pattern and an evaluation of its application in forensic identification. J. Forensic Odontostomatol., 22(1):1-4, 2004.

Mustafa, A. G.; Allouh, M. Z. \& Alshehab, R. M. Morphological changes in palatal rugae patterns following orthodontic treatment. J. Forensic Leg. Med., 31:19-22, 2015.

Ohtani, M.; Nishida, N.; Chiba, T.; Fukuda, M.; Miyamoto, Y. \& Yoshioka, $\mathrm{N}$. Indication and limitations of using palatal rugae for personal identification in edentulous cases. Forensic Sci. Int., 176(2-3):178-82, 2008.

Patil, S. B.; Patil, M. S.; Smita, B. R. \& Hebbar, K. G. Rugae dimensions and their significance in forensic dentistry. J. Forensic Dent. Sci., 8(1):57-8, 2016.

Rath, R. \& Reginald, B. A. Palatal rugae: An effective marker in population differentiation. J. Forensic Dent. Sci., 6(1):46-50, 2014.

Shetty, D. K.; Mali, S.; Divakar, H. D.; Amit, P.; Dhairaysheel, E. \& Harsh, U. Palatal rugae patterns as a bioindicator for forensic identification in Kodava and Tibetan populations of India. J. Int. Oral Health, 7(Suppl. 2):57-9, 2015.

Shukla, D.; Chowdhry, A.; Bablani, D.; Jain, P. \& Thapar, R. Establishing the reliability of palatal rugae pattern in individual identification (following orthodontic treatment). J. Forensic Odontostomatol., 29(1):20-9, 2011.

Taneva, E. D.; Johnson, A.; Viana, G. \& Evans, C. A. 3D evaluation of palatal rugae for human identification using digital study models. J. Forensic Dent. Sci.,7(3):244-52, 2015.

Thabitha, R. S.; Reddy, R. E.; Manjula, M.; Sreelakshmi, N.; Rajesh, A. \& Kumar, V. L. Evaluation of palatal rugae pattern in establishing identification and sex determination in Nalgonda children. J. Forensic Dent. Sci., 7(3):232-7, 2015.

Wu, X. P.; Han, J. N.; Fen, P.; Wang, Y. J. \& Bing, L. Application of palatal rugae morphology in forensic identification. Int. J. Morphol., 34(2):510$3,2016$.

\section{Corresponding author:}

Li Bing

Stomatology Hospital

Shanxi Medical University

63 Xinjian Road,Taiyuan 030001

CHINA

Received: 24-08-2016

Accepted: 09-01-2017

E-mail: libing-1975@163.com 